\title{
初回破裂時には明らかでなかった破裂微小脳動脈瘤からの 再出血に対する血管内手術
}

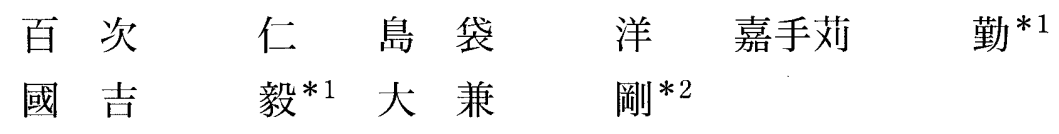

\section{Endovascular Treatment for Recurrent Subarachnoid Hemorrhage from the Ruptured Small Aneurysm not clearly seen at the First Rupture}

by

Jin Momoji, M.D., Hiroshi Shimabukuro, M.D., Tsutomu Kadekaru, M.D. ${ }^{* 1}$, Tsuyoshi Kuniyoshi, M.D. ${ }^{* 1}$, and Tsuyoshi Ookane, M.D. ${ }^{* 2}$

from

Department of Neurosurgery, Naha City Hospital,

${ }^{* 1}$ Department of Neurosurgery, Nanbu Tokushukai Hospital, and

${ }^{* 2}$ Department of Radiology, Nanbu Tokushukai Hospital

We present a case of recurrent subarachnoid hemorrhage (SAH) attributed to rupture of an aneurysm which was not treated because it was not clearly seen on angiography at the first SAH.

A 67-year-old woman presented with consciousness disturbance (Hunt \& Kosnik grade IV) and left hemiparesis. A CT scan revealed massive SAH (Fisher group 3). Angiography showed a $5 \mathrm{~mm}$ right carotid cave aneurysm and a bulging at the posterior communicating artery origin which was thought to be an infundibular dilatation. Emblization for the carotid cave aneurysm was successfully performed. Sudden consciousness disturbance occurred 7 days after embolization, and CT scan revealed recurrent SAH. Because of severe brain swelling due to vasospasm, the patient was treated conservatively. After a ventricle-peritoneal shunt was performed for normal pressure hydrocephalus, the patient recovered but had a left hemiparesis.

Angiography obtained two months after embolozation showed complete occlusion of the previously embolized aneurysm, and the enlarged aneurysm thought to be an infundibular dilatation, previously. Both episodes of SAH were considered to be attributed to this aneurysm. Because it was a very small aneurysm, endovascular treatment was considered extremely difficult and dangerous. But at the request of her family, we performed endovascular embolization of aneurysm successfully. Postoperative course of the patient was uneventful.

We stressed that early follow-up angiography is very important even after successeful occlusion of small carotid cave aneurysms because small carotid cave aneurysms tend not to rupture and another aneurysm which was unclear at the first angiography may appear clearly, after a while as in to our case.

(Received February 17, 2003; accepted October 27, 2003)

Key words : endovascular treatment, Gugulielmi detachable coil, recurrent subarachnoid hemorrhage, carotid cave aneurysm, follow-up angiography

Jpn J Neurosurg（Tokyo） $13: 401-406,2004$

\footnotetext{
*1那覇市立病院脳神経外科 $/ \bar{T} 902-8511$ 那覇市古島 2-31-1〔連絡先：百次 仁〕

Address reprint requests to : Jin Momoji, M.D., Department of Neurosurgery, Naha City Hospital, 2-31-1 Furujima, Naha-shi, Okinawa 902-8511, Japan

*2南部徳洲会病院脳神経外科 $* 3$ 南部徳洲会病院放射線科
} 

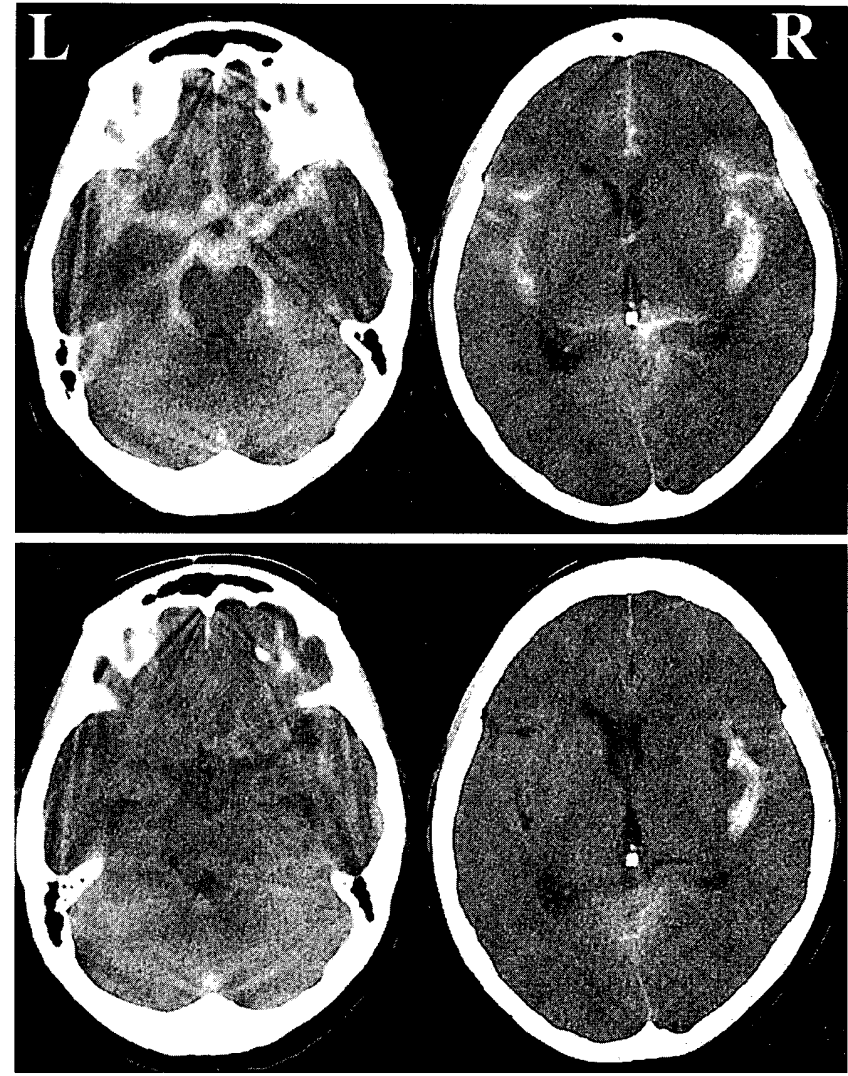

Fig. 1 Upper row: CT scan obtained after admission showed a thick subarachnoid hemorrhage.

Lower row: CT scan obtained after first embolization and intrathecal administration of UK showed a slight residual hematoma in the right insular cistern.

\section{はじめに}

近年の血管内手術の発達により，急性期のクモ膜下出 血（以下, SAH）症例にも脳動脈瘤瘤内塞栓術が行われ ることが多くなった。最小限の侵襲で再破裂を予防し， 早期に離床が図れるため, きわめて有望な治療法である. しかし, 塞栓術の成功後も再出血をきたす症例が稀にあ る. 今回, われわれは初回出血時の血管撮影で真の破裂 動脈瘤が確認できずに合併した未破裂動脈瘤を塞栓し， 処置を行わなかった真の破裂動脈瘤が 1 週間後に再出 血したきわめて稀な症例を経験した，多発性動脈瘤症例 への血管内手術の適用, 限界などについて検討したので 報告する.

\section{症 例}

患 者: 67 歳, 女性. 特記すべき既往歴, 家族歴なし. 現病歴：2001 年 7 月 6 日, クモ膜下出血 (SAH) で発 症し，近医に搬送された。意識レベルはJCS 100, Hunt

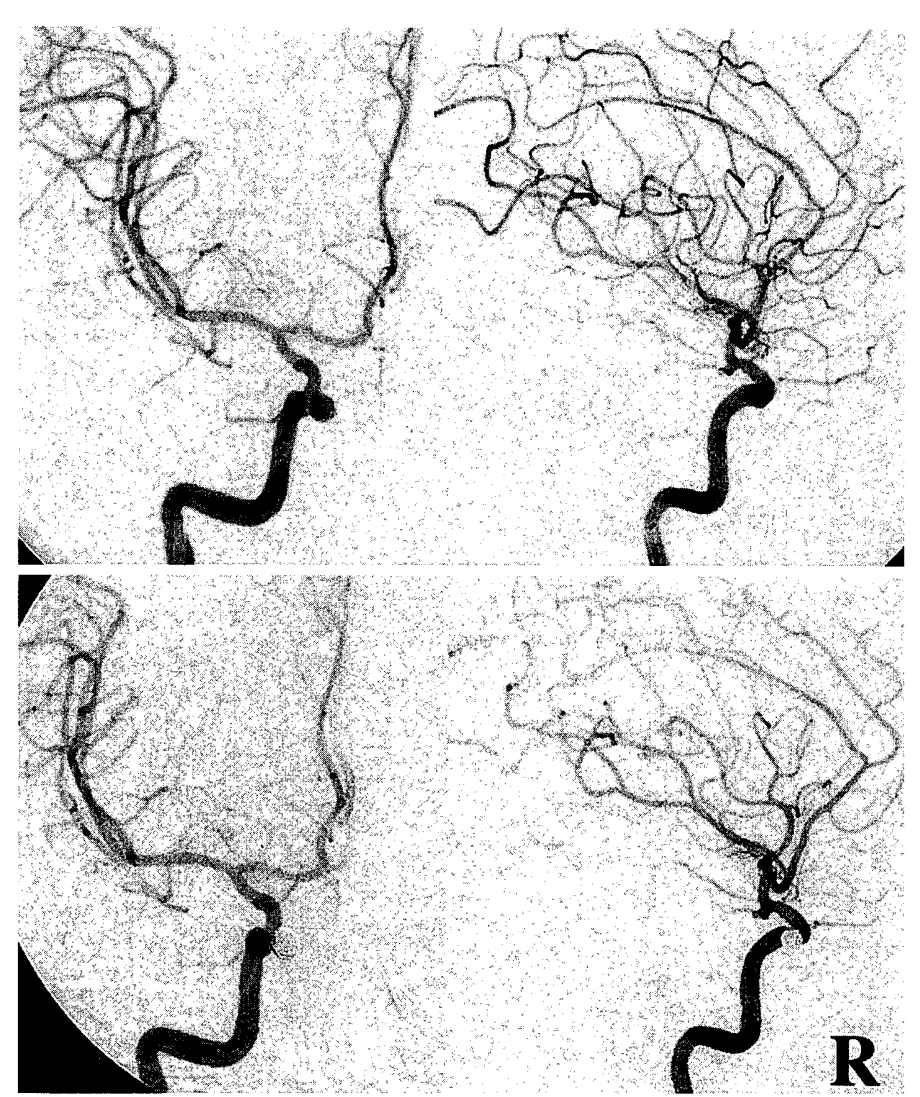

Fig. 2 Angiogram before (upper row) and after (lower row) first embolization

Carotid cave aneurysm was occluded completely.

\& Kosnik grade IVで左片麻痺を呈していた。頭部 CT で は Fisher group 3 の SAH が認められた (Fig. 1 上段). 同 日の血管撮影で右内頸動脈 (C 2-3 portion, carotid cave) に内側向きの約 $4 \times 5 \mathrm{~mm}$ の囊状動脈瘤が認められた (Fig. 2 上段)。また, 後交通動脈分岐部にもわずかに膨 らみが認められたが, 漏斗状拡大と判断された。手術的 困難さ，患者のレベル (grade IV), また家族の希望から 当院に carotid cave 動脈瘤の塞栓術を依頼され, 7 月 7 日 に施行した。

第 1 回血管内手術：全身麻酔下にて右大腿動脈に $6 \mathrm{Fr}$. sheath を穿刺し, 6Fr. guiding catheter を右内頸動脈に留 置した。先端を 3 次元的に蒸気で形成した 10 size の microcatheter を, GT guidewire (TERUMO) で留中央部 へ誘導した. Gugulielmi detachable coil (GDC) $4 \mathrm{~mm} \times 6$ $\mathrm{cm}$ から計 8 本, $40 \mathrm{~cm}$ 挿入し, 完全閉塞で終了した (Fig. 2 下段).

術後経過: 脳血管攣縮の予防目的に術直後からアルガ トロバン，オザグレルナトリウムなどを使用し，翌日か ら腰椎ドレナージよりウロキナーゼ（UK） 6 万単位を 3 日間投与した。 7 月 8 日には，ほぼ意識清明で JCS 1 , 


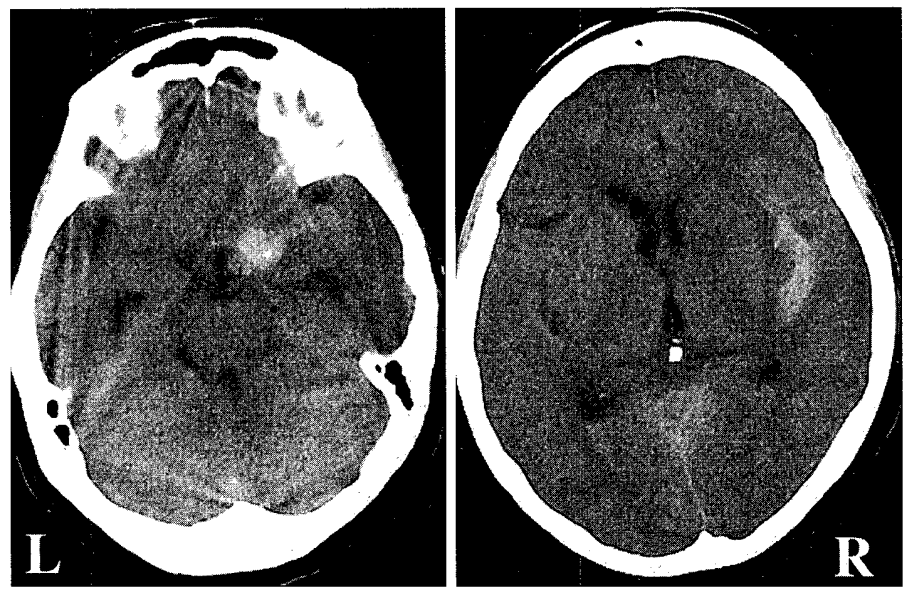

Fig. 3 CT scan after second rupture of aneurysm showed vague hematoma and a small low density area in the right insular portion.

GCS 15 に回復した. 7 月 10 日にはCT 上, 右 insular cisternのみに SAH が残存した（Fig. 1 下段）。 7 月 14 日， 意識レベルが JCS 100 まで低下し,左片麻痺が出現した。 CT では右の carotid cistern に SAH, 中大脳動脈領域に一 部低吸収域が認められた（Fig. 3)。SAH は塞栓部位の周 囲ににじみ出る程度の少量で, 意識レベルも低かったの で，止血剤を投与し，経過観察した。その後，脳血管攣 縮の進行に対し, 高気圧酸素療法も追加された。術後約 1 力月ごろに正常压水頭症を呈したため, 8 月 21 日に脳 室腹腔短絡術を施行し，意識レベルは改善した。

9 月 4 日の follow-up の血管撮影で前回塞栓した動脈 瘤のコイルの形は変化なかったが，わずかに認められた 右内頸動脈後交通動脈分岐部の膨らみが, L 字状に約 $2 \times 4 \mathrm{~mm}$ と明らかに増大していたので， 2 度の出血は同 部の破裂によるものと考光られた（Fig. 4 中），病変がき わめて小さく，血管内手術は困難であることを説明して も意識清明となった患者本人も家族も開頭術を拒否し， 初回に成功した血管内手術を強く希望した. 主治医は苦 渋の選択を迫られ，最終的に血管内手術を 9 月 13 日に 施行した。

第 2 回血管内手術：全身麻酔下にて右大腿動脈に $7 \mathrm{Fr}$. sheath を穿刺し, 7Fr. guiding catheter を右内頸動脈に留 置した。2回目の手術は瘤がきわめて小さく，すでに 2 度破裂していると考えられたので, 術中破裂の危険性が 高いこと，また前交通動脈を介する右前大脳動脈への対 側からの側副血行は良好で, 右大脳半球中大脳動脈領域 はすでに広範な梗塞を呈していることもあり，破裂した 場合には内頸動脈の一過性の遮断, 最悪の場合には永久 的な閉塞も辞さないつもりで，あらかじめ microballoon catheter を瘤遠位部, 内頸動脈終末部に留置した. 10 size
の microcatheter を GT guidewire $90^{\circ}$ で誘導し, 瘤内へ誘 導した．慎重に guidewire を操作し， microcatheter 先端 を瘤の奥にうまく留置し得た. GDC $10 \mathrm{soft}, 2 \mathrm{~mm} \times 2 \mathrm{~cm}$ を 2 本留置した。新たに認められた瘤の増大部分は造影 されなくなったので，手技を終了した（Fig. 4 右）.

術後経過: 術後はアルガトロバンを血栓塞栓症予防に 使用し, 続いて抗血小板薬の内服で特に問題なく経過し た. 11 月 22 日の血管撮影で 2 個の動脈瘤とも変わりな く閉塞を確認した(Fig. 5). 左片麻痺を残したが Glasgow outcome scale の moderately disabled の状態で施設に 移った。術 1 年後も特に変わりなく生活している。

\section{考 察}

破裂脳動脈瘤の治療において近年の血管内手術の発展 により，良好な成績が報告されるようになった ${ }^{10)}$ 。しか し, 初回出血時の塞栓術成功後も再出血をきたす症例が ある，その原因は大きく 2 つに分けられ，(1)瘤の再増大 や coil compaction により初回出血部位から再出血する場 合，(2)塞栓した動脈瘤とは別の動脈瘤から出血する場合 である．後者はさらに1）初回出血後の最初の血管撮影 で真の破裂動脈瘤が確認できず, 未破裂動脈瘤を塞栓し, 処置を行わなかった真の破裂動脈瘤から再出血する場 合，2）破裂動脈瘤を塞栓したが，未破裂動脈瘤が後に 破裂する場合が考えられる。

本例は初回血管撮影では漏斗状拡大と思われた後交通 動脈分岐部が再破裂後の血管撮影で拡大しており，かつ 前回の塞栓部位は変化がなかったので, 後交通動脈分岐 部が真の破裂部位であると判断し，後者(2)の 1) と考え られた。文献を涉猟し得たかぎりでは，このような症例 

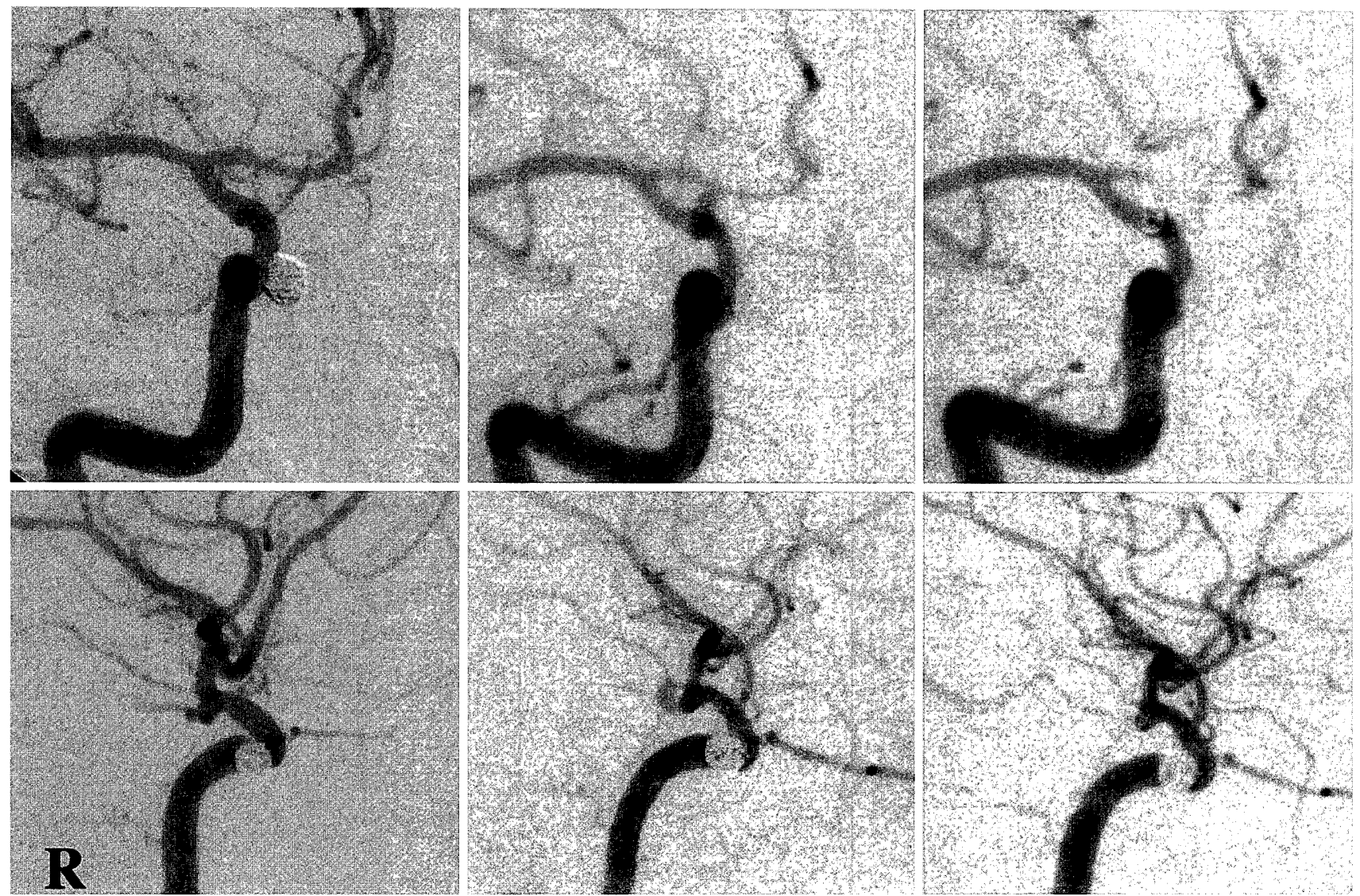

Upper row : anteroposterior view

Fig. 4 Serial angiogram

Lower row : lateral view

Left : after first embolization Center : before second embolization

Right : after second embolization

The internal carotid posterior communicating aneurysm was enlarged and occluded completely. The posterior communicating artery was preserved.

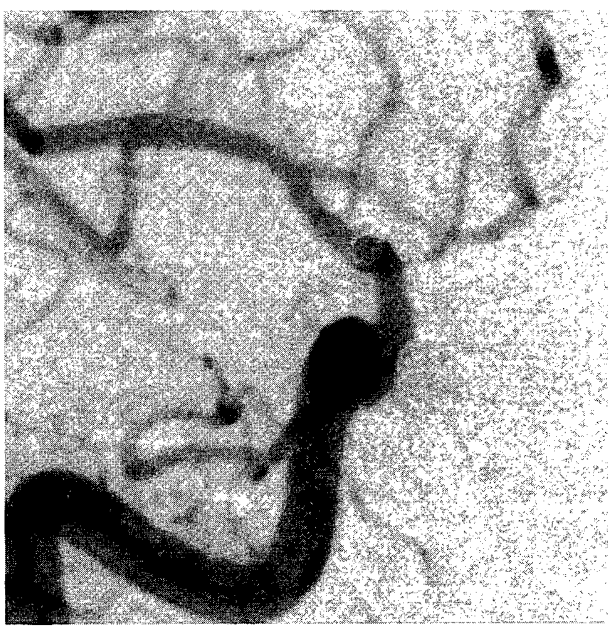

Anteroposterior view

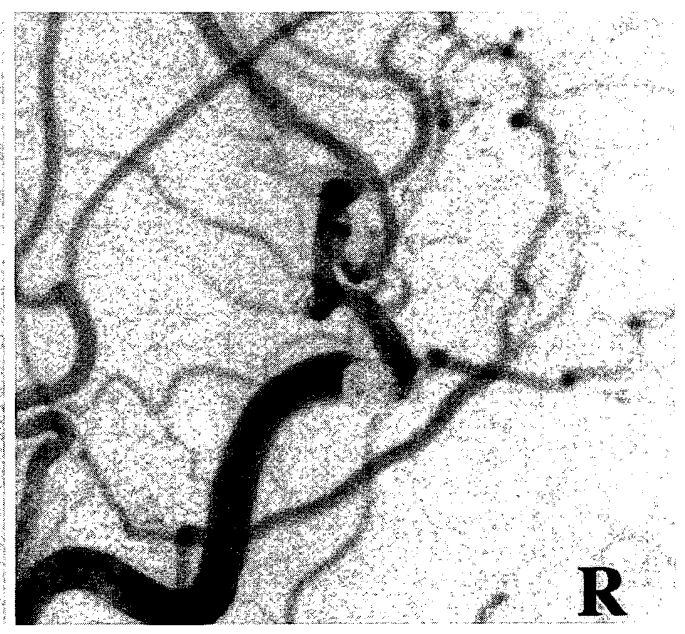

Lateral view

Fig. 5 Follow-up angiogram 10 weeks after second embolization Both aneurysms were occluded completely. 
の報告は認められなかったが，臨床上，十分にあり得る ケースであり，破裂動脈溜にも血管内手術の適応がます ます拡がっていくなかで，注意を喚起すべく報告した．

SAH で発症した症例に抢いて血管撮影で明らかな霊 状動脈溜が 1 個認められた場合, 出血の部位と一致すれ ばまずそこが出血源と考光られるが，血管内手術の場合 は，直接動脈瘤近傍の状態をみることができないので， 本例のようにたまたま同時に存在した未破裂動脈溜を処 置してしまい，破裂動脈瘤を放置してしまう危険性が生 じる，本例で初回治療で直達手術を施行していたとして も，破裂部位には抢そらく wrapping しかできなかったと 思わ机るが，両動脈溜とも処置できる点では直達手術の 優位性を示すものであり，血管内手術の限界を認めざる を得ない.しかし，たと兄ば CT 上，血腫が左右均等に あり, 両側の内頸動脈に複数の動脈瘤が認められる場合 などでは破裂部位が特定困難であり, 血管内手術の方が, 一期的に治療しやすいという優位性もある ${ }^{8)}$.

本例のような小さな動脈溜は血管内手術手技による破 裂の危険性が高く ${ }^{4)}$ ，その場合，動脈瘤そのものが吹き 飛んでしまい，塞栓術の継続が困難な状態になる危険性 もあり, guidewire や catheterの操作は, 通常の何倍も 注意して破裂を予防しなければならない6(6)7. そのために は高解像度の biplane の血管撮影装置を使用し, 場合に よっては microballoon catheter で親動脈の一時的, さら には永続的な遮断も行える準備が必要と思われる。

本例に対する 2 回目の血管内手術については, 非難も 多々あると思われるが，患者の開頭術拒否の場合に仕方 なく選択されることもあるのではなかろうか. 本例は minor leak ながら再出血をきたしており，出血源に対す る処置は不可欠と考元られた。しかし，意識清明となっ た患者自身とその家族に開頭術を拒否され，次の選択肢 としてかろうじて承諾を得られたものであり，主治医と して苦橴の選択であったと思わ机る。 そこで血管内手術 が可能かどうか当院にコンサルトされた，その時点で開 頭術の適応を再度検討していただいたが，患者の同意が どうしても得られないとのことで，われわれもやむなく 血管内手術に踏み切ることにしたものである.このよう に血管内手術が非常に困難と考光られても施行せざるを 得ない場合には, 最悪の場合を想定して, 前述のように 十分な準備をしておくことが重要と思われた。

また, carotid cave の動脈瘤については直達手術の困難 さのため, 血管内手術のよい適応とされている ${ }^{119)}$. しか し, carotid caveの動脈瘤は, 他の動脈瘤の破裂時などに 偶然発見される未破裂動脈瘤が多く，また，小さな動脈 瘤の破裂率は低いとされている ${ }^{1) 3}$. Thornton $ら^{9)}$ が治療
した paraclinoid の動脈留は 71 個中，以前の出血 4 個を 含めて 17 個 (23.9\%)のみが破裂動脈溜であった. Nutik ${ }^{3)}$ の報告では 17 個中 4 個のみが破裂動脈瘤で，それらは すべて $10 \mathrm{~mm}$ 以上であった. Roy ら ${ }^{5)}$ は 13 個中 10 個が 偶然発見され，3 個の破裂動脈溜のうち 2 個が小さな動 脈㢚であったが，正確な大きさの記載はなかった。自験 例では 16 例中長径 $10 \mathrm{~mm}$ 以上が 6 例あったが，そのう ち 2 例のみが破裂動脈瘤で, 残り 10 例は $10 \mathrm{~mm}$ 未満の 未破裂動脈瘤であった。

carotid cave は distal dural ring の粗な硬膜の結合のた めに SAH を生じる可能性はあるが2), 周囲構造物のた め, 総じて小さな carotid cave の動脈熘は破裂しにくい と考元られている.さらに近年の精度の高い MRA で, 小さな carotid cave 動脈瘤はますます発見される率が高 くなると考えられるため，小さな未破裂動脈瘤に対する 治療の適応は今後，慎重でなければならない。しかし動 脈瘤が大きくなると治療困難な部位でもあるため, MRA または 3D-CT などで経過観察をして増大傾向が認めら れた場合には，小さくても治療を検討すべきと思われる。

本例の場合, 他に明らかな動脈溜は認められず, carotid cave の動脈瘤が破裂部位と決めてかかってし まったが，小さな carotid cave の動脈瘤の場合には他に も疑わしい部位がないか常々疑ってかからなければなら ない，疑わしい部位がある場合には carotid cave の動脈 溜に対する血管内手術が成功裹に終わっても, 術後早期 に follow-up の血管撮影を行うべきであると思われた。

\section{結 語}

血管内手術施行時には明らかでなかった破裂動脈溜 が，その後増大し，再出血した多発性動脈瘤の 1 例を経 験した直接動脈瘤を確認できない血管内手術の場合, 真 の破裂動脈熘なのかの判断はきわめてむずかしいが, carotid cave の小さな動脈溜の破裂率は低いため, 疑わし い部分があれば治療成功後も早期の follow-up の血管撮 影が重要であると思われた。

\section{文 献}

1) Gurian JH, Viñuela F, Guglielmi G, Gobin P, Duckwiler GR: Endovascular embolization of superior hypophyseal artery aneurysms. Neurosurgery 39: 1150-1156, 1996.

2) Kobayashi S, Kyoshima K, Gibo H, Hegde SA, Takemae T, Sugita $\mathrm{K}$ : Carotid cave aneurysms of the internal carotid artery. J Neurosurg $\quad \mathbf{7 0}: 216-221,1989$.

3) Nutik SL: Ventral paraclinoid carotid aneurysms. J Neurosurg 69: 340-344, 1988.

4) Ricolfi F, Guerinel C, Blustajn J, Combes C, Brugieres P, 
Melon E, Gaston A : Rupture during treatment of recently ruptured aneurysms with Guglielmi electrodetachable coils. AJNR 19: 1653-1658, 1998.

5) Roy D, Raymond J, Bouthillier A, Bojanowski MW, Moumdjian R, LEspérance G: Endovascular treatment of ophthalmic segment aneurysms with Guglielmi detachable coils. AJNR 18: 1207-1215, 1997.

6) Shanno GB, Armonda RA, Benitez RP, Rosenwasser RH: Assessment of acutely unsuccessful attempts at detachable coiling in intracranial aneurysms. Neurosurgery 48: 1066-1074, 2001.

7) Sluzewski M, Bosch JA, van Rooij WJ, Nijssen PCG, Wijnalda $\mathrm{D}$ : Rupture of intracranial aneurysms during treat- ment with Guglielmi detachable coils: Incidence, outcome, and risk factors. J Neurosurg 94:238-240, 2001.

8) Solander S, Ulhoa A, Viñuela F, Duckwiler GR, Gobin YP, Martin NA, Frazee JG, Guglielmi G: Endovascular treatment of multiple intracranial aneurysms by using Guglielmi detachable coils. J Neurosurg 90:857-864, 1999.

9) Thornton J, Aletich VA, Debrun GM, Alazzaz A, Misra M, Charbel F, Ausman JI: Endovascular treatment of paraclinoid aneurysms. Surg Neurol 54:288-299, 2000.

10) Viñuela F, Duckwiler G, Mawad M: Guglielmi detachable coil embolization of acute intracranial aneurysm: Perioperative anatomical and clinical outcome in 403 patients. J Neurosurg 86: 475-482, 1997.

要

旨

\section{初回破裂時には明らかでなかった破裂微小脳動脈瘤からの再出血に対する血管内手術}

百次仁 島袋 洋 嘉手苅 勤 國吉 毅 大兼 剛

初回破裂時には，径 $5 \mathrm{~mm}$ の carotid cave の囊状動脈瘤が明らかであったため, 同部に対する血管 内手術を施行し完全閉塞が得られたが，その際には明らかでなかった後交通動脈分岐部破裂動脈瘤が その後増大し再出血した, 多発性動脈瘤の 1 例を経験した. 直接動脈瘤を確認できない血管内手術の 場合, 真の破裂動脈瘤なのかの判断はきわめてむすかいい場合があるが, 治療成功後も疑わしい部分 があれば，早期の follow-up の血管撮影が重要であると思われた．特に carotid cave の小さい動脈瘤 の破裂率は低いため, 他に真の破裂動脈瘤がないか，十分な検索が必要と思われた。

脳外誌 $13: 401-406,2004$

\section{Editorial Comment}

臨床上十分にあり得るケースではあるが，クモ膜下出 血の症例において，実際は未破裂動脈瘤を治療してしま い, 後に隠されていた破裂動脈瘤が姿を現し, 再出血し たという意味では, トリッキーで示唆に富む症例といえ る．著者らも述べているが，クモ膜下出血の症例で，さ ほど大きくない carotid cave aneurysm しか認められな かった場合には，その流域に，ほかに破裂脳動脈瘤が隠 されていないかどうか，十分に注意する必要があるとい うことであろう。

本論文においてその点は賛同できるが，治療方法につ いては少し議論しなければならない. 初回の carotid cave aneurysm に対する血管内手術には異論はないが, 第 2 回目の内頸動脈後交通動脈分岐部（以下 IC-PC）動 脈䈏の血管内手術については，すぐには同意できない，

著者らも文中に述べていることであり，そ扎はあまで も患者側の希望で，開頭術を拒否された結果の苦渋の選 択ということである．患者側の希望というとそれで決ま りということになるが, 患者側の希望の根拠となる医療 者側の説明はどうあるべきであろうか，本例の治療を考 えてみると，少なくともある程度きちんとしたネックを もつ（コイル塞栓術が可能であったという事実がある） 直径 $2 \mathrm{~mm}$ の, しかも最終出血からほぼ 2 か月経過した,
再手術ではない IC-PC 動脈瘤の開頭直達クリッピング 術のリスクがどの程度かは, 経験を積んだ脳外科医には 容易に想像がつくことであろう。一方血管内手術はとい うと，著者らも述べているごとく，本例の場合は術中破 裂のリスクが通常よりもかなり高く, 最悪の場合を想定 した準備が必要であるとの認識である，数字で表すのは むずかしいとしても, 本例のコイル塞栓術の合併症発生 の予想リスクは, 開頭直達クリッピング術の予想リスク の数倍に上るといわざるを得ないであろう。しかも本例 は，すでに経過中に脳室腹腔短絡術という外科手術が施 行されており，IC-PC 動脈瘤に対する血管内手術の選択 の根拠は, 患者側の希望以外にはなかったと思われる.

私自身は脳動脈瘤の治療に扔いて，患者の利益を考慮 した場合に，むしろ血管内治療を推進したい立場ではあ るが, 現状では外科手術と血管内手術で得手不得手があ り,その点を十分に考慮した適応の選択が重要であろう。 本例はその点も考慮されたうえでの患者側の希望という ことと考えたいが，読者もその点を理解して本論文を読 んでいただけ扎ばと思う。

琉球大学医学部脳神経外科 兵頭明夫 